\title{
Colebrookea oppositifolia
}

\author{
Lutesh Kumar $^{* 1}$, Pooja Sharma ${ }^{1,2}$, Dinesh Kumar ${ }^{1}$ \\ ${ }^{1}$ Sri Sai College of Pharmacy, Manawala, Amritsar-143115, Punjab, India \\ ${ }^{2}$ Department of Pharmaceutical Sciences and Drug Research, Punjabi University Patiala, Punjab, India
}

Address for Correspondence: Lutesh Kumar; luteshbhagat@gmail.com

Received:

01.03.2019

Accepted:

25.03.2019

\section{Keywords}

Colebrookea

oppositifolia;

Phytochemical;

Pharmacognostic

; Acteoside;

Antioxidant;

Neuroprotective.
ABSTRACT: Colebrookea oppositifolia is a valuable traditional therapeutic plant belonging to the family Lamiaceae. It is a dense and wool like shrub that mostly found in subtropical regions of some countries like China and India. It has been widely used for the treatment of nervous system disorders like epilepsy. The active constituents of the plant have exhibited antioxidant, antimicrobial and antifungal properties which are considered due to the presence of polyphenols and flavonoids as chief chemical constituents. Flavonoids like quercetin, landenein, chrysin and 5, 6, 7-trimethoxy flavones cause protein denaturation of microbial cell wall. The plant has been greatly used for the preparation of many herbal medicines which are used for treating traumatic injuries, fever, rheumatoid arthritis, headache and gastric problems. From the bark of the plant, a phenylethanoid glycoside named as acteoside, is separated and have been evaluated for its several therapeutic and pharmacological activities like immunomodulatory, neuroprotective, hepatoprotective, analgesic, anti-tumour, antispasmodic, antioxidant, antibacterial, vasorelaxant activities, strong free radical scavenger and improving sexual function. Acteoside showed neuroprotective activities against $A \beta$-peptide which is neurotoxic and causes apoptosis. The petroleum ether extract of the plant leaves gives many active compounds like sitosterol, n-triacontane, hydroxydotriacontyl ferulate, acetyl alcohol and 3,7,42tetramethoxy flavones which have shown hepatoprotective activities. The plant should be evaluated further for the estimation of some other benefits.@ 2019 iGlobal Research and Publishing Foundation. All rights reserved.

Cite this article as: Kumar, L..; Sharma, P.; Kumar, D. Colebrookea oppositifolia. Indo Global J. Pharm. Sci., 2019; 9(2Suppl.): 132. DOI: http://doi.org/10.35652/IGJPS.2019.92S30 .

Indo Global Journal of Pharmaceutical Sciences( ISSN 2249 1023; CODEN- IGJPAI; NLM ID: 101610675) indexed and abstracted in CrossRef (DOI Enabling), UGC CARE Journal List, EMBASE(Elsevier), National Library of Medicine (NLM) Catalog, ResearchGate, Publons, CAS (ACS), Index Copernicus, Google Scholar and many more. For further details, visit http://iglobaljournal.com

This is a special issue as an outcome of 'RAPSCON-2019' sponsored by APTI and organized by Sri Sai College of Pharmacy, Manawala, Amritsar, Punjab, India. Relaxation offered in journal format. 